Article

\title{
Potential Enhancement of the In-Situ Bioremediation of Contaminated Sites through the Isolation and Screening of Bacterial Strains in Natural Hydrocarbon Springs
}

\author{
Pietro Rizzo ${ }^{1}{ }^{1}$, Matilde Malerba ${ }^{1}$, Antonio Bucci ${ }^{2, *}{ }^{\circledR}$, Anna M. Sanangelantoni ${ }^{1}$, \\ Sara Remelli ${ }^{1}$ and Fulvio Celico ${ }^{1}$ (I) \\ 1 Department of Chemistry, Life Sciences and Environmental Sustainability, University of Parma, \\ Parco Area delle Scienze 157/A, 43124 Parma, Italy; pietro.rizzo2@studenti.unipr.it (P.R.); \\ matilde.malerba@studenti.unipr.it (M.M.); annamaria.sanangelantoni@unipr.it (A.M.S.); \\ sara.remelli@unipr.it (S.R.); fulvio.celico@unipr.it (F.C.) \\ 2 Department of Biosciences and Territory, University of Molise, C.da Fonte Lappone, 86090 Pesche, Italy \\ * Correspondence: antonio.bucci@unimol.it; Tel.: +39-0874-404-156
}

Received: 5 June 2020; Accepted: 21 July 2020; Published: 23 July 2020

\begin{abstract}
Petroleum hydrocarbon contamination (PHC) is an issue of major concern worldwide. These compounds represent the most common environmental pollutants and their cleaning up is mandatory. The main goal of this research was to analyze microbial communities in a site in southern Italy characterized by the presence of hydrocarbons of natural origin by using a multidisciplinary approach based on microbiological, geological and hydrological investigations. Bacterial communities of two springs, the surrounding soils, and groundwater were studied through a combination of molecular and culture-dependent methodologies to explore the biodiversity at the study site, to isolate microorganisms with degradative abilities, and to assess their potential to develop effective strategies to restore the environmental quality. Next-generation sequencing revealed the dominance of species of the Proteobacteria phylum but also the presence of other autochthonous hydrocarbon-oxidizing microorganisms affiliated to other phyla (e.g., species of the genera Flavobacterium and Gordonia). The traditional cultivation-based approach led to the isolation and identification of 11 aerobic hydrocarbon-oxidizing proteobacteria, some of which were able to grow with phenanthrene as the sole carbon source. Seven out of the 11 isolated bacterial strains produced emulsion with diesel fuel (most of them showing emulsifying capacity values greater than $50 \%$ ) with a high stability after $24 \mathrm{~h}$ and, in some cases, after $48 \mathrm{~h}$. These results pave the way for further investigations finalized at (1) exploiting both the degradation ability of the bacterial isolates and/or microbial consortia to remediate hydrocarbon-contaminated sites and (2) the capability to produce molecules with a promoting effect for oil polluted matrices restoration.
\end{abstract}

Keywords: hydrocarbon springs; groundwater; bioremediation; microbiological-hydrogeological investigations; next-generation sequencing (NGS)

\section{Introduction}

Hydrocarbon pollution is a widespread phenomenon that affects human health and the environment, including air, water, and soil [1]. Hydrocarbons of petroleum origin, despite being essential energy resources and one of the raw materials needed for different types of industries [2], are classified as priority pollutants [3]. Many of them, such as Polycyclic Aromatic Hydrocarbons (PAHs), are recalcitrant and highly dangerous, as they can be hemotoxic, carcinogenic and teratogenic [3-7]. 
Accordingly, over the decades, the awareness to protect the environment has increased, especially now that pollution is recognized as one of the most severe and urgent issues society has to face. The sources of environmental contamination caused by hydrocarbons are different, such as accidents in the transport of fuel by ships and tankers, leaks from underground tanks and service stations, oil extraction and processing operations, release of oily waste generated by industries that use oil in the production of plastics, solvents, pharmaceuticals and cosmetics [8,9]. The cleaning up of these contaminants from the environment is mandatory and can be reached by using physical-chemical or biological strategies [1,10]. Biological approaches have shown several advantages compared to traditional physical-chemical treatments, being more cost effective and allowing for the complete mineralization of the organic pollutant [10,11]. For this reason, bioremediation has been widely studied and is an environmentally friendly technology used for the removal of hydrocarbons in both terrestrial and aquatic ecosystems [12]. The bioremediation of contaminated sites by organic compounds is based on the stimulation of the catabolic activity of microorganisms capable of using polluting organic contaminants as a source of carbon and energy. So far, bioremediation is performed through different practices such as biostimulation (the addition of macro- and/or micronutrients to enhance indigenous biomass growth and pollutant degradation), bioaugmentation (inoculation with pollutant-degrading microorganisms) or combined biostimulation and bioaugmentation [13].

The microbial community in a given ecosystem is crucial for the biodegradation of pollutants to occur [14]. In fact, bacterial adaptation, defined as an evolutionary process in which shifts in the microbial community composition or abundances take place in response to changes in environmental conditions and contaminant content, can improve the biodegradation rate of a chemical.

On the other hand, the existence of a microbial potential does not always lead to in situ biodegradation since many limitations, such as insufficient biomass, utilization of a wide range of substrates, competitive inhibition, or catabolite repression, can all inhibit the process [14].

From this perspective, the analysis and characterization of microorganisms involved in biodegradation processes are of the utmost importance for the ultimate success of bioremediation. Furthermore, it is essential not only to dwell upon microbial communities but also have knowledge on the geological, hydrogeological and geochemical characteristics of the environment in which they live because several other factors may influence their activities [5,15].

The main aim of the present work was to analyze microbial communities in soil, spring and groundwaters from a study site in southern Italy characterized by the presence of hydrocarbons of natural origin, through a combination of culture-dependent and molecular methods. In addition, the comprehension of the geological and hydrogeological features of the aquifer system was fundamental to identify the active circuits that continuously feed the studied soil, springs and groundwaters, all year round, and could influence the composition of the bacterial communities. Some of the bacterial isolates were identified and screened for their ability to grow in the presence of different pollutants and emulsifying capacity, to assess their potential as candidates in biotechnological applications to treat and recover the polluted environmental matrices.

\section{Materials and Methods}

\subsection{Study Area}

The study area (Tramutola, Agri Valley, Southern Italy; Figure 1 and Figure S1) is characterized by some natural outcrops of hydrocarbons, whose existence was already known from the end of the 19th century [16]. The Agri Valley is an intramountain valley, with a North-West/South-East orientation, a length of $30 \mathrm{~km}$ and an average width of $12 \mathrm{~km}$. This study is focused on a small portion of the valley that includes two springs (S1 and S2) with natural hydrocarbon outcrops close to wells drilled in the early 20th century by the AGIP Company (at present ENI, Milano, Italy) for gas and oil extraction. Among these wells, the artesian well $\mathrm{P}_{\text {art }}$ was included in this research. The springs S1 and S2 (Figure S2), as well as the $\mathrm{P}_{\text {art }}$ well, are located along an E-W fault where the Apulian carbonate 
platform and Rio Cavolo Unit (Oligocene) [17] crop out (Figure 2). The Rio Cavolo Unit is made up of clays, micaceous limestone and rare marly layers. The $\mathrm{P}_{\text {art }}$ well (404 $\mathrm{m}$ deep) intercepted oil and gas at different depths $[18,19]$.

Different hydrogeological series complexes crop out at the study site [20]: (i) carbonate rocks belonging to the Mesozoic carbonate platform series complexes, characterized by very high permeability due to a well-developed fracture network and karst conduits; (ii) sedimentary rocks belonging to the syn-orogenic turbidite series complexes and the outer and the inner basins' series complexes, characterized by a permeability ranging from very low to low due to a mixed pore-fracture network. Along the Cavolo stream and the whole Agri Valley, heterogeneous alluvial sediments crop out, whose hydraulic conductivity ranges between less than $1 \times 10^{-8}$ to $2 \times 10^{-2} \mathrm{~m} / \mathrm{s}$ [21].

The hydrocarbon springs S1 and S2 flow out along a fault zone which enhances fluid upflow and allows the mixing of hydrocarbons and gas (mainly $\mathrm{CH}_{4}$ and $\mathrm{H}_{2} \mathrm{~S}$ ) [22] with the local groundwater, which is primarily fed by the nearby carbonate aquifer (Figure 2) [19]. The groundwater intercepted by the $\mathrm{P}_{\text {art }}$ well is fed by a more prolonged pathway in a relatively deep aquifer made of Scisti Silicei (Figure 3) [19]. This deep groundwater naturally flows eastwards, towards the alluvial aquifer of the Agri Valley.
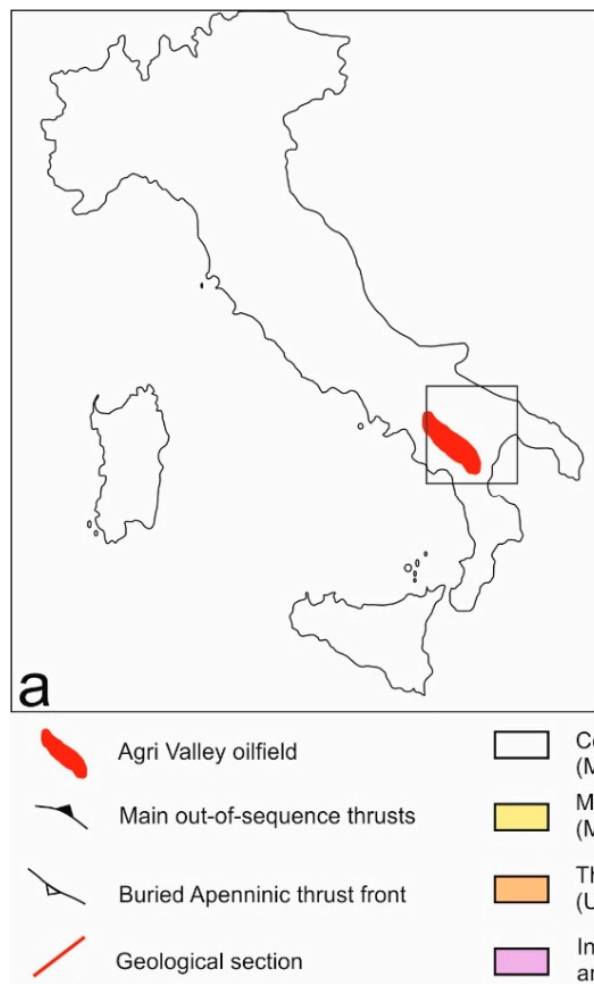

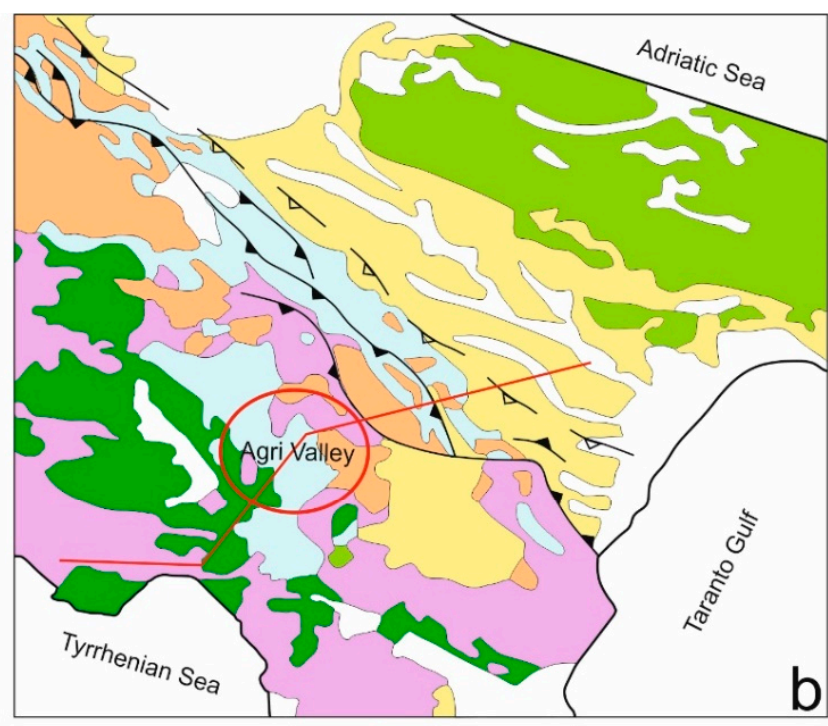

Continental and volcanic deposits (Middle Pleistocene-Holocene)

Marine to continental deposits (Middle Pliocene-Lower Pleistocene)

Thrust-sheet-top deposits (Upper Tortonian-Upper Pliocene)

Internal Apenninic nappes and related ancient thrust-sheet-top-deposits
Apenninic carbonate platform units and related siliciclastic foredeep deposits

Lagonegro-Molise-Sannio basinal units and related siliciclastic foredeep Apulian carbonate platform units

Figure 1. (a) Localization of the study area. (b) Schematic structural-geological map of the southern Apennines from Patacca et al. [23], modified. 


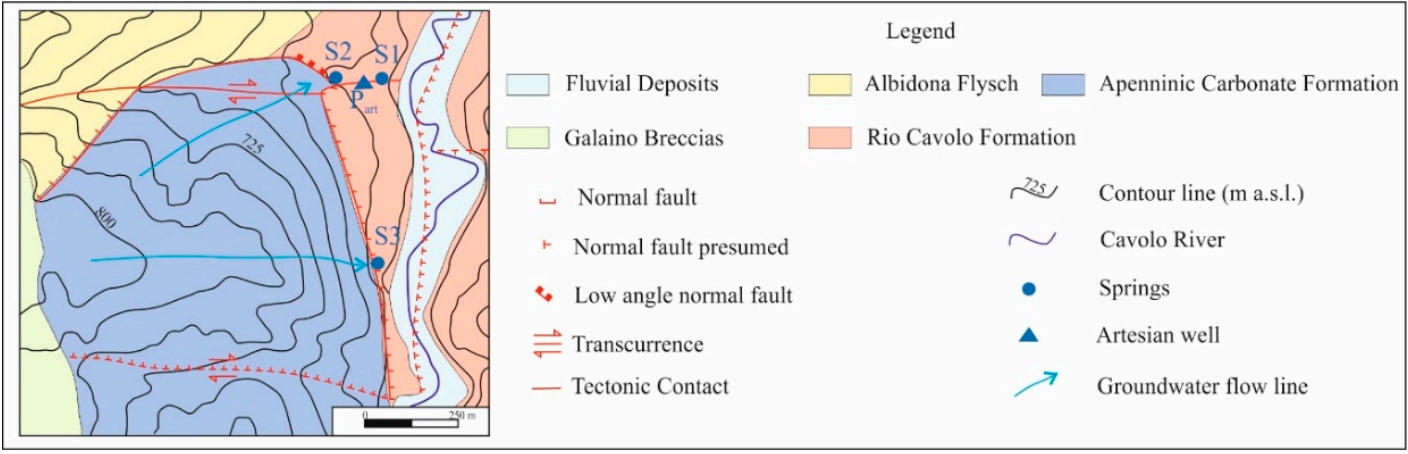

Figure 2. Hydrogeological map of the study area (from Rizzo et al. [19]); the blue points and the triangle show the location of the investigated springs S1 and S2 and the artesian well $\mathrm{P}_{\text {art }}$ (the geological sketch is taken from Olita [18], modified).

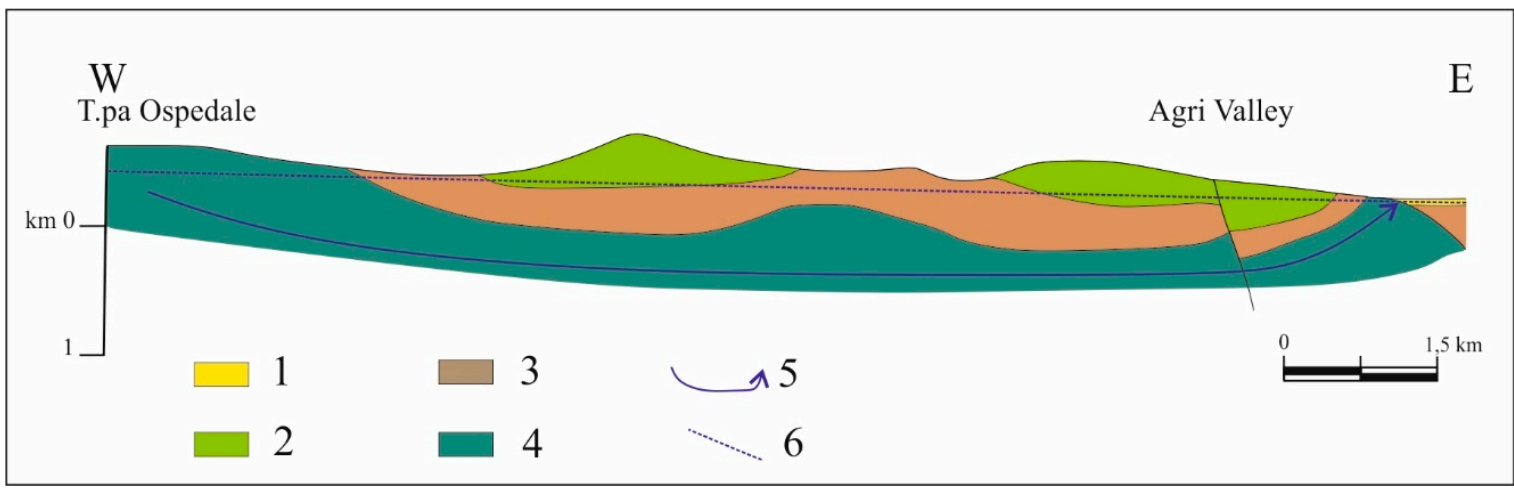

Figure 3. Hydrogeological schetch of the Scisti Silicei aquifer (Rizzo et al. [19]; based on the geological section of Menardi Noguera and Rea [24]): the (1) alluvial complex, (2) carbonate complex, (3) low-permeability complex, (4) Scisti Silicei complex, (5) groundwater flow line, (6) and hydraulic head.

\subsection{Hydrogeological and Chemical-Physical Investigations}

The discharge of the two springs S1 and S2 was measured in low flow (July 2018), in early recharge (October 2018) and in late recharge (March 2019). Moreover, it was measured hourly during a rainfall event to analyze the time lag between precipitation and springs' recharge increase. The flow rate of the $\mathrm{P}_{\text {art }}$ artesian well was not measurable but, based on some historical data, its order of magnitude is about $30 \mathrm{~m}^{3} / \mathrm{h}$ [19]. In conjunction with discharge measurements and sample collection for chemical and microbiological analyses (March 2019), physico-chemical parameters such as temperature $\left({ }^{\circ} \mathrm{C}\right), \mathrm{pH}$, electrical conductivity $(\mathrm{EC} \mu \mathrm{S} / \mathrm{cm})$, redox potential (ORP millivolts) and total dissolved solids (TDS ppm), were measured with the multiparameter HANNA probe (mod. HI9828, HANNA Instruments, Villafranca Padovana, Italy).

Three water and two soil samples were collected to analyze PAHs and benzene, toluene, ethylbenzene, and xylene (BTEX) content. These data were compared with those acquired during sampling campaigns carried out in 2013 (unpublished data). One-liter (L) black glass bottles and 40-milliliter colorless glass vials (filled with water or soil) were used for PAHs and BTEX analyses, respectively. The analyses were performed at Biochemie Lab S.r.l. following the EPA 3510C $1996+$ EPA 8270E 2018 protocol for PAHs and the EPA 5030C 2003 + EPA 8015D 2003 protocol for BTEX in water and EPA 3550C 2007 + EPA 8015D 2003 protocol for PAHs and the EPA 5021A 2014 + EPA 8015D 2003 protocol for BETX in soil [25-30]. 


\subsection{Next-Generation Sequencing (NGS) for Bacterial Community Analyses}

For bacterial community analyses, spring and groundwater samples $(4 \mathrm{~L})$ and two soil samples $(0.5 \mathrm{~g})$, collected close to the springs ( $0.5 \mathrm{~m}$ distance), were used. Water samples were filtered through sterile mixed esters of cellulose filters (S-Pak ${ }^{\mathrm{TM}}$ Membrane Filters, $47 \mathrm{~mm}$ diameter, $0.22 \mu \mathrm{m}$ pore size, Millipore Corporation, Billerica, MA, USA) within $24 \mathrm{~h}$ from the collection. Bacterial DNA extraction from filters and soils was performed using the commercial kit FastDNA SPIN Kit for soil (MP Biomedicals, LLC, Solon, OH, USA) and FastPrep ${ }^{\circledR}$ Instrument (MP Biomedicals, LLC, Solon, $\mathrm{OH}, \mathrm{USA})$. After the extraction, DNA integrity and quantity were evaluated by electrophoresis in $0.8 \%$ agarose gel containing $1 \mu \mathrm{g} / \mathrm{mL}$ of Gel-RedTM (Biotium, Inc., Fremont, CA, USA). The bacterial community profiles in the samples were generated by next-generation sequencing (NGS) technologies at the Genprobio Srl Laboratory. Partial 16S rRNA gene sequences were obtained from the extracted DNA by polymerase chain reaction (PCR), using the primer pair Probio_Uni and Probio_Rev, targeting the V3 region of the bacterial 16S rRNA gene [31]. Amplifications were carried out using a Veriti Thermal Cycler (Applied Biosystems, Foster City, CA, USA), and PCR products were purified by the magnetic purification step involving the Agencourt AMPure XP DNA purification beads (Beckman Coulter Genomics $\mathrm{GmbH}$, Bernried, Germany) in order to remove primer dimers. Amplicon checks were carried out as previously described [31]. Sequencing was performed using an Illumina MiSeq sequencer (Illumina, Hayward, CA, USA) with MiSeq Reagent Kit v3 chemicals. The fastq files were processed using a custom script based on the QIIME software suite [32]. Paired-end read pairs were assembled to reconstruct the complete Probio_Uni/Probio_Rev amplicons. Quality control retained sequences with a length between 140 and $400 \mathrm{bp}$ and mean sequence quality score $>20$, while sequences with homopolymers $>7 \mathrm{bp}$ and mismatched primers were omitted. To calculate downstream diversity measures, operational taxonomic units (OTUs) were defined at $100 \%$ sequence homology using DADA2 [33]; OTUs not encompassing at least two sequences of the same sample were removed. All reads were classified to the lowest possible taxonomic rank using QIIME2 [32,34] and a reference dataset from the SILVA database v132 [35]. The biodiversity of the samples (alpha-diversity) was calculated with the Shannon index. Similarities between samples (beta-diversity) were calculated by weighted uniFrac. The range of similarities is calculated between values 0 and 1 . Principal Coordinate Analysis (PCoA) representations of beta-diversity were performed using QIIME2. In the PCoA, each dot represented a sample that is distributed in tridimensional space according to its own bacterial composition.

\subsection{Enrichment and Isolation of Bacteria with Potential Hydrocarbon Degrading Ability}

To isolate hydrocarbon-oxidizing bacteria, 1-mL aliquots of water from springs S1 and S2 and $\mathrm{P}_{\text {art }}$ well, and $5 \mathrm{~g}$ of soils collected close to the springs ( $0.5 \mathrm{~m}$ distance), were inoculated in sterile test tubes containing peptone water. Then, $1 \mathrm{~mL}$ of the suspensions was inoculated in $5 \mathrm{~mL}$ of liquid Bushnell-Haas (BH) medium $\left(\mathrm{MgSO}_{4}-0.2 \mathrm{~g} / \mathrm{L} ; \mathrm{CaCl}_{2}-0.02 \mathrm{~g} / \mathrm{L} ; \mathrm{KH}_{2} \mathrm{PO}_{4}-1.0 \mathrm{~g} / \mathrm{L} ; \mathrm{K}_{2} \mathrm{HPO}_{4}-1.0 \mathrm{~g} / \mathrm{L}\right.$; $\mathrm{NH}_{4} \mathrm{NO}_{3}-1.0 \mathrm{~g} / \mathrm{L} ; \mathrm{FeCl}_{3}-0.05 \mathrm{~g} / \mathrm{L}$ ) [36]. Diesel fuel was added at a concentration of $2 \%$ as the only carbon source, to select the hydrocarbon degrading bacteria. Cultures were, then, incubated at $28^{\circ} \mathrm{C}$ for seven days with agitation. The enrichment step was repeated for seven cycles. From the fourth enrichment cycle, $100-\mu \mathrm{L}$ aliquots of the cultures were spread on Bushnell-Haas (BH) agar medium supplemented with diesel fuel as a carbon source. Diesel fuel was supplied by diffusion through a soaked paper disk (9-mm diameter).

The colonies grown on the plates were repeatedly streaked over the entire surface of fresh $\mathrm{BH}$ agar medium supplemented with diesel fuel and, finally, on TSA (Tryptone Soy Agar) plates to be sure to obtain pure cultures. 


\subsection{Identification of the Bacterial Strains Isolated from Spring, Groundwater and Soil Samples}

After the enrichment, the isolated bacterial strains were analyzed by Amplified Ribosomal DNA Restriction Analysis (ARDRA) with the restriction endonuclease HaeIII, to group them on the basis of the restriction profiles. One representative strain for each ARDRA haplotype was selected for the $16 \mathrm{~S}$ rDNA gene partial sequencing at BMR Genomics srl in Padua (Italy). The obtained sequences were then compared with those stored in the GenBank database at the NCBI (National Center for Biotechnology Information) by using the BLAST (Basic Local Alignment Search Tool) program (http://www.ncbi.nlm.nih.gov/blast). The partial 16S rDNA gene sequences were deposited in GenBank under the accession numbers MT703034 to MT703044.

\subsection{Growth Response of Bacterial Isolates in the Presence of Different Hydrocarbons as the Sole Carbon Source}

The potential degradation ability of some bacterial strains has been evaluated in $\mathrm{BH}$ agar medium containing different hydrocarbons (Naphthalene, Phenanthrene, Pristane and Hexadecane) as the sole carbon source. Naphthalene and Phenanthrene occur, at room temperature, in the solid state as granules; after spreading the individual bacterial strains onto the medium surface, the granules were added directly to the surface of the medium. The Pristane and the Hexadecane occur, at room temperature, in the liquid state and were delivered by diffusion from a soaked paper disk placed in the center of the plate. The plates were incubated at $30^{\circ} \mathrm{C}$ for 4 weeks, monitoring the growth every week.

\subsection{Determination of the Emulsifying Capacity and Emulsion Index}

The assay used to determine the emulsifying capacity (EC\%) and the emulsion index (E) is a re-adaptation of the method previously described by Mohebali et al. [37]; $2 \mathrm{~mL}$ of pure cultures of the isolated strains, grown in $\mathrm{BH}$ medium at $28^{\circ} \mathrm{C}$ with agitation until the optical density (OD) at the wavelength of $600 \mathrm{~nm}$ reached 1.0 (OD measured with a Cary $50 \mathrm{UV}$-Vis spectrophotometer, VARIAN INC, Palo Alto, CA, USA), were transferred to test tubes and diesel fuel $(0.2 \mathrm{~mL})$ was added; the test tubes were vigorously shaken for $30 \mathrm{~s}$ and left standing for $10 \mathrm{~min}$. The samples showing an emulsion over the liquid were selected and, once the emulsion was stabilized, more diesel fuel $(0.2 \mathrm{~mL})$ was added; the procedure was repeated until a distinct and clear fraction of non-emulsified diesel fuel was observed on the surface of the emulsion.

The emulsifying capacity (EC\%) was calculated using the following formula:

$$
\mathrm{EC}=\frac{\text { total diesel volume }}{\text { initial aqueous phase volume }} \times 100
$$

The emulsion index (E) was calculated after the test for the emulsifying capacity; the variation of the emulsion thickness was measured after $24\left(\mathrm{E}_{24}\right)$ and $48\left(\mathrm{E}_{48}\right) \mathrm{h}$ with the following formula:

$$
\mathrm{E}=100 \times \frac{\text { emulsion thickness at } \mathrm{t}_{\mathrm{x}}}{\text { emulsion thickness at } \mathrm{t}_{0}}
$$

where $t_{x}$ is the time in which the measurement was taken (e.g., $\left.t_{24}, t_{48}\right)$ and $t_{0}$ is the test start time.

\section{Results}

\subsection{Hydrogeological and Physico-Chemical Features}

The flow rate of both hydrocarbon springs S1 and S2 slightly varied overtime during the observation period (1.3 to $1.7 \mathrm{~m}^{3} / \mathrm{h}$ at spring S1; 1.0 to $1.2 \mathrm{~m}^{3} / \mathrm{h}$ at spring S2), suggesting an active groundwater pathway. The spring regime, further analyzed through hourly measurements during a rainfall event (about $11 \mathrm{~mm}$ in a few tens of hours), demonstrated a very rapid and synchronous response of spring $\mathrm{S} 1\left(2.5\right.$ to $\left.3.6 \mathrm{~m}^{3} / \mathrm{h}\right)$ and spring $\mathrm{S} 2\left(2.0\right.$ to $\left.2.5 \mathrm{~m}^{3} / \mathrm{h}\right)$ to precipitation. 
The main physico-chemical features of hydrocarbon springs and $\mathrm{P}_{\text {art }}$ well are synthesized in Table 1. The temperature ranged from 13.9 to $15.7^{\circ} \mathrm{C}$ in spring waters, while it varied between 27.5 and $27.8^{\circ} \mathrm{C}$ in $\mathrm{P}_{\text {art }}$ waters. The $\mathrm{pH}$ was constantly close to neutrality. Redox potential was slightly negative. The electrical conductivity was higher and more variable in $\mathrm{P}_{\text {art }}$-water (1444 to $2433 \mu \mathrm{S} / \mathrm{cm}$ ) than in springs waters (460 to $507 \mu \mathrm{S} / \mathrm{cm})$.

Table 1. Physico-chemical features of spring- and groundwaters.

\begin{tabular}{cccccc}
\hline Sample & Date & Temperature & $\mathbf{p H}$ & Redox Potential & Electrical Conductivity \\
\hline $\mathrm{ID}$ & $\mathrm{dd} / \mathrm{mm} / \mathrm{yyyy}$ & ${ }^{\circ} \mathrm{C}$ & & $\mathrm{mV}$ & $\mu \mathrm{S} / \mathrm{cm}$ \\
\hline $\mathrm{P}_{\text {art }}$ & $19 / 07 / 2018$ & 27.8 & 6.8 & -26.0 & 1444 \\
$\mathrm{P}_{\text {art }}$ & $29 / 10 / 2018$ & 27.6 & 6.8 & -30.0 & 2433 \\
$\mathrm{P}_{\text {art }}$ & $18 / 03 / 2019$ & 27.5 & 6.8 & -7.5 & 2432 \\
$\mathrm{~S} 1$ & $19 / 07 / 2018$ & 15.6 & 6.9 & -60.0 & 507 \\
$\mathrm{~S} 1$ & $29 / 10 / 2018$ & 15.6 & 6.8 & -51.8 & 494 \\
$\mathrm{~S} 1$ & $18 / 03 / 2019$ & 15.7 & 6.9 & -33.4 & 494 \\
$\mathrm{~S} 2$ & $19 / 07 / 2018$ & 14.3 & 6.9 & -20.0 & 460 \\
$\mathrm{~S} 2$ & $29 / 10 / 2018$ & 15.6 & 6.9 & -15.0 & 467 \\
$\mathrm{~S} 2$ & $18 / 03 / 2019$ & 13.9 & 6.9 & -4.0 & \\
\hline
\end{tabular}

\subsection{Chemical Analyses of Spring, Groundwater and Soil Samples}

Chemical analyses revealed detectable PAHs and no BTEX in both springs S1 and S2 (Table 2). Neither PAHs nor BTEX were detected in groundwater sampled from the $P_{\text {art }}$ artesian well. These results agree with those obtained by ENI in 2013 (unpublished data).

Table 2. Results of chemical analyses of spring- and groundwater samples.

\begin{tabular}{|c|c|c|c|}
\hline Parameter & Spring S1 & Spring S2 & $P_{\text {art }}$ Well \\
\hline Unit & $\mu \mathrm{g} / \mathrm{L}$ & $\mu \mathrm{g} / \mathrm{L}$ & $\mu \mathrm{g} / \mathrm{L}$ \\
\hline Benzene & $<0.1$ & $<0.1$ & $<0.1$ \\
\hline Ethylbenzene & $<1.0$ & $<1.0$ & $<1.0$ \\
\hline p-Xylene & $<1.0$ & $<1.0$ & $<1.0$ \\
\hline Styrene & $<1.0$ & $<1.0$ & $<1.0$ \\
\hline Toluene & $<1.0$ & $<1.0$ & $<1.0$ \\
\hline Benzo(a)anthracene & $<0.002$ & $<0.002$ & $<0.002$ \\
\hline Benzo(a)pyrene & $<0.002$ & $<0.002$ & $<0.002$ \\
\hline Benzo(b)fluoranthene & $<0.002$ & 0.354 & $<0.002$ \\
\hline Benzo(k)fluoranthene & $<0.002$ & 0.0341 & $<0.002$ \\
\hline Benzo(g,h,i)perylene & $<0.002$ & 0.199 & $<0.002$ \\
\hline Chrysene & $<0.002$ & $<0.002$ & $<0.002$ \\
\hline Dibenzo(a,h)anthracene & $<0.002$ & $<0.002$ & $<0.002$ \\
\hline Indene $(1,2,3-c, d)$ pyrene & $<0.002$ & 0.101 & $<0.002$ \\
\hline Pyrene & $<0.002$ & $<0.002$ & $<0.002$ \\
\hline Acenaphthene & $<0.002$ & $<0.002$ & $<0.002$ \\
\hline Acenaphthylene & $<0.002$ & $<0.002$ & $<0.002$ \\
\hline Anthracene & $<0.005$ & 0.726 & $<0.005$ \\
\hline Naphthalene & 0.00231 & $<0.002$ & $<0.002$ \\
\hline Phenanthrene & $<0.002$ & 0.465 & $<0.002$ \\
\hline Fluoranthene & $<0.005$ & 0.166 & $<0.005$ \\
\hline Fluorene & $<0.005$ & $<0.005$ & $<0.005$ \\
\hline Benzo(J)fluoranthene & $<0.001$ & 0.0140 & $<0.001$ \\
\hline Dibenzo(a,e)pyrene & $<0.001$ & $<0.001$ & $<0.001$ \\
\hline Dibenzo(a,l)pyrene & $<0.001$ & $<0.001$ & $<0.001$ \\
\hline Dibenzo(a,i)pyrene & $<0.001$ & $<0.001$ & $<0.001$ \\
\hline Dibenzo(a,h)pyrene & $<0.001$ & $<0.001$ & $<0.001$ \\
\hline$\Sigma$ PAHs & $<0.002$ & 0.689 & $<0.002$ \\
\hline
\end{tabular}


Consistent with the results obtained in spring water samples, several PAHs were detected in soils collected close to both the investigated springs. Higher concentrations were found close to spring S2 (Table 3).

Table 3. Results of chemical analyses of soil samples.

\begin{tabular}{ccc}
\hline Parameter & Soil S1 & Soil S2 \\
\hline Unit & $\mathrm{mg} / \mathrm{kg}$ & $\mathrm{mg} / \mathrm{kg}$ \\
Benzene & $<0.01$ & $<0.01$ \\
Etilbenzene & $<0.05$ & $<0.05$ \\
Toluene & $<0.05$ & $<0.05$ \\
Xylenes & $<0.05$ & $<0.05$ \\
o-Xylene & $<0.05$ & $<0.05$ \\
p,m-Xylenes & $<0.05$ & $<0.05$ \\
Benzo(a)anthracene & 0.16 & 0.95 \\
Benzo(a)pyrene & $<0.01$ & $<0.01$ \\
Benzo(b)fluoranthene & $<0.05$ & 3.93 \\
Benzo(g,h,i)perylene & 0.28 & 1.45 \\
Benzo(k)fluoranthene & $<0.05$ & 0.58 \\
Chrysene & 0.21 & 1.23 \\
Dibenzo(a,e)pyrene & $<0.01$ & $<0.01$ \\
Dibenzo(a,h)anthracene & $<0.01$ & 0.34 \\
Dibenzo(a,h)pyrene & $<0.01$ & $<0.01$ \\
Dibenzo(a,i)pyrene & $<0.01$ & $<0.01$ \\
Dibenzo(a,l)pyrene & $<0.01$ & 0.10 \\
Indene(1,2,3-c,d)pyrene & 0.05 & 0.19 \\
Pyrene & $<0.05$ & 0.61 \\
\& PAHs & $<1.0$ & 8.25 \\
\hline
\end{tabular}

\subsection{S Ribosomal RNA Gene Next-Generation Sequencing (NGS)}

MiSeq runs produced 294,432 final reads (Table 4). The 16S rRNA gene sequences generated in this study have been deposited in the NCBI Sequence Read Archive under the accession numbers PRJNA629324 and PRJNA636951. The rarefaction analysis, a measure used to estimate the alpha diversity in samples and gauge whether or not sequencing efforts captured the microbial diversity, showed a relatively higher biodiversity in soil samples and spring S2-water (Shannon index values ranging from 7.59 to 8.88) compared to spring S1-water and $\mathrm{P}_{\text {art }}$-groundwater (index values of 3.40 and 4.32, respectively; Figure S3). Principal Coordinate Analysis (PCoA) based on weighted uniFrac index revealed a clear separation of soil, spring, and groundwater samples and highlighted marked differences between the S1 spring water microbial community and all the others (Figure 4).

Table 4. Number of $16 \mathrm{~S}$ rDNA sequences obtained after next-generation sequencing (NGS) analysis for spring water, groundwater and soil samples.

\begin{tabular}{cc}
\hline Sample & Final Read Number \\
\hline S1 Water & 49,512 \\
S1 Soil & 61,621 \\
S2 Water & 61,065 \\
S2 Soil & 68,893 \\
$P_{\text {art }}$ Water & 53,341 \\
\hline
\end{tabular}




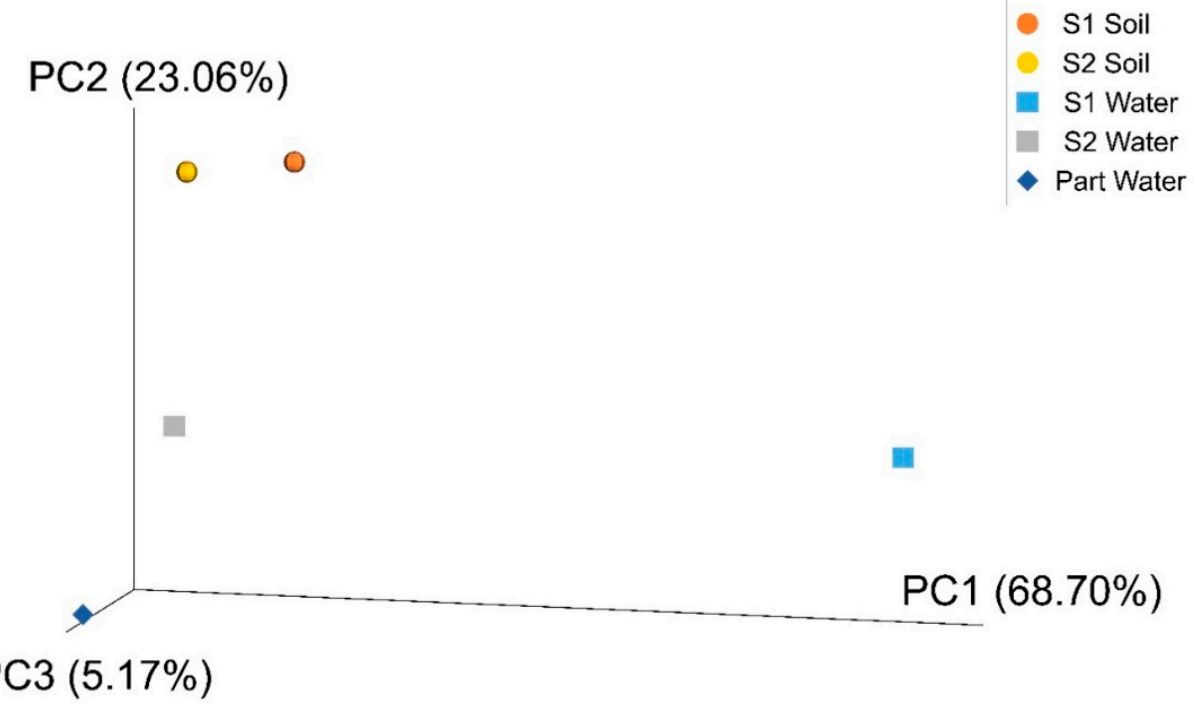

Figure 4. Principal Coordinate Analysis (PCoA). The plot was generated using a weighted uniFrac distance matrix. Soil, spring water, and groundwater samples are shown.

The NGS results allowed us to obtain detailed information about the composition of microbial communities in spring water, groundwater and soil samples.

The phylum Proteobacteria was dominant in most of the analyzed samples, reaching relative abundance values of up to $93.60 \%$ (sample $\mathrm{P}_{\text {art }}$ ) (Figure 5). Other phyla abundantly represented were Epsilonbacteraeota in the spring water sample S1 (52.48\%), and Actinobacteria, found in the two soil samples at percentages of $16.38 \%$ and $22.20 \%$.

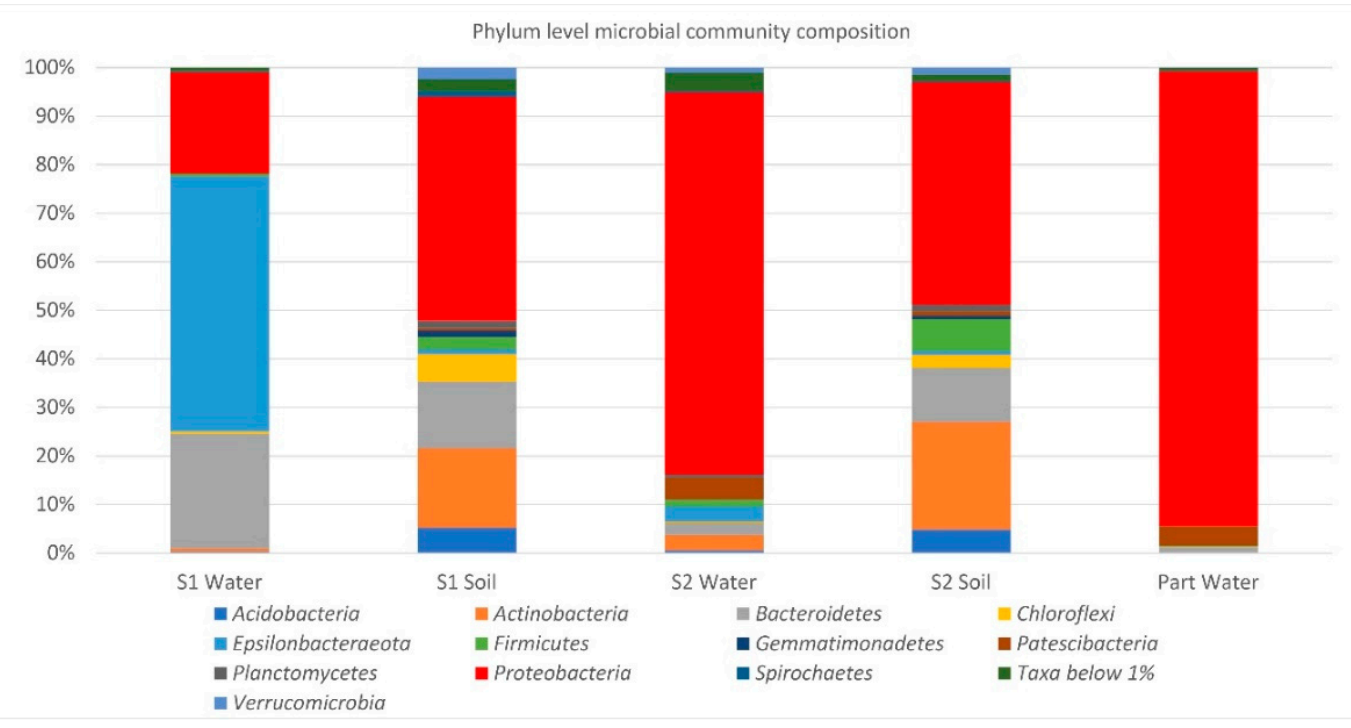

Figure 5. Phylum level microbial community composition in spring water, Part well, and soil samples.

In line with the PCoA results, significant differences between the two spring water microbial communities were detectable already at this level. In fact, Epsilonbacteraeota, Bacteroidetes, and Proteobacteria were the three major phyla in water from the spring S1 with relative abundance values of $52.48 \%, 23.63 \%$, and $20.67 \%$, respectively, whereas Proteobacteria dominated in S2 spring water $(78.63 \%)$ followed by Patescibacteria $(4.51 \%)$ and Actinobacteria $(3.17 \%)$.

At a lower taxonomic level (Figure 6), the genus Hydrogenophaga, affiliated to the phylum Proteobacteria, was found at higher percentages in $\mathrm{P}_{\text {art }}(34.09 \%)$ and S2 water samples $(15.17 \%)$. 
Hydrogenophaga and some other bacterial genera retrieved in the samples, such as Flavobacterium, Gordonia, Sulfuritalea, and Rhodoferax, are known to include microorganisms able to oxidize hydrocarbons [38-43].

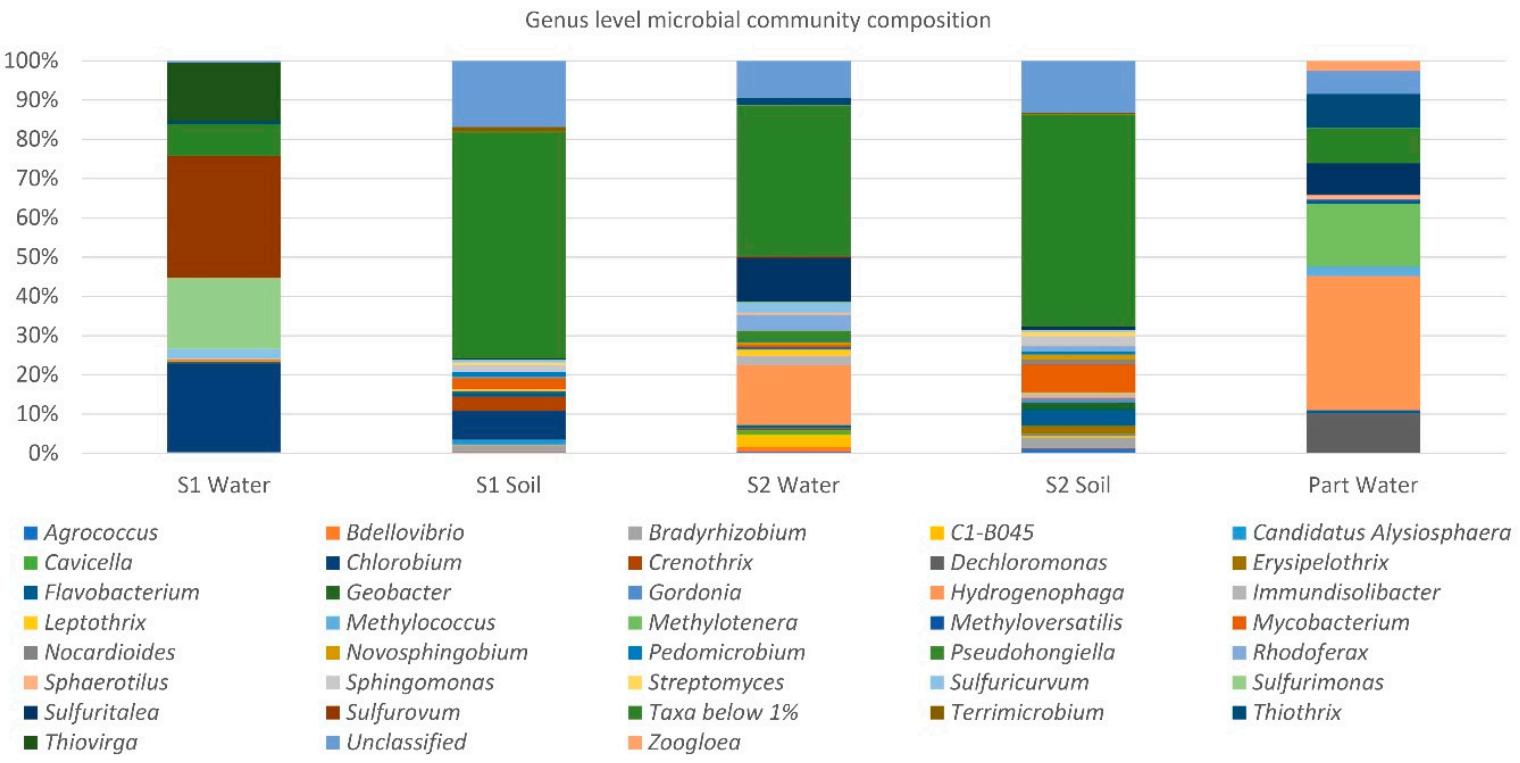

Figure 6. Genus level microbial community composition in spring water, $\mathrm{P}_{\text {art }}$ well, and soil samples.

\subsection{Isolation and Identification of Bacterial Strains}

Following the seven enrichment cycles on $\mathrm{BH}$ medium with diesel fuel as the only carbon source, 26 bacterial strains with different colony morphology were isolated from springs S1 and S2, $\mathrm{P}_{\text {art }}$ artesian well and soils.

An identification number from 1 to 26 was assigned to each strain. The 26 bacterial isolates were subjected to ARDRA analysis that allowed us to group them based on electrophoretic profiles. ARDRA analysis was also performed on five strains $(1 \mathrm{C}-5 \mathrm{C})$ obtained from S1 and S2 spring waters in previous experiments carried out at the study site (unpublished data). Seventeen bacterial isolates, representing all the ARDRA haplotypes, were chosen for 16S rRNA gene partial sequencing. Eleven bacterial strains were identified (Table 5), while the remaining isolates could not be rendered perfectly axenic in isolation procedures and, therefore, the sequencing failed. Some of the 16S rRNA gene sequences showed an identity $<97 \%$ with those stored in the GenBank database, suggesting that the bacterial isolates could be representatives of novel genera or species (Table 5). 
Table 5. Results of 16S rRNA gene partial sequencing of bacterial strains isolated from spring water, groundwater and soil samples.

\begin{tabular}{|c|c|c|c|}
\hline Strain & Sequence Accession Number & $\begin{array}{l}\text { Most Closely Related Organism } \\
\text { (Accession Number) }\end{array}$ & Identity $(\%)$ \\
\hline $3 \mathrm{C}$ & MT703034 & $\begin{array}{c}\text { Achromobacter spanius strain LMG } 5911 \\
\text { (NR_025686) }\end{array}$ & 97.80 \\
\hline $1 \mathrm{C}$ & MT703035 & $\begin{array}{l}\text { Pseudomonas protegens strain CHA0 } \\
\text { (NR_114749) }\end{array}$ & 99.78 \\
\hline 3 & MT703036 & 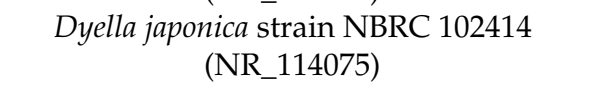 & 90.69 \\
\hline 4 & MT703037 & $\begin{array}{l}\text { Pseudomonas protegens strain CHA0 } \\
\text { (NR_114749) }\end{array}$ & 98.42 \\
\hline 7 & MT703038 & $\begin{array}{c}\text { Cupriavidus metallidurans CH34 } \\
\text { (NR_074704) }\end{array}$ & 98.16 \\
\hline 8 & MT703039 & $\begin{array}{l}\text { Pseudomonas protegens strain CHA0 } \\
\text { (NR_114749) }\end{array}$ & 98.19 \\
\hline 10 & MT703040 & $\begin{array}{c}\text { Stenotrophomonas maltophilia strain ATCC } \\
13637 \text { (NR_112030) }\end{array}$ & 99.19 \\
\hline 15 & MT703041 & $\begin{array}{c}\text { Stenotrophomonas tumulicola strain } \\
\text { T5916-2-1b (NR_148818) }\end{array}$ & 90.86 \\
\hline 16 & MT703042 & $\begin{array}{c}\text { Stenotrophomonas maltophilia strain ATCC } \\
13637 \text { (NR_112030) }\end{array}$ & 86.38 \\
\hline 18 & MT703043 & Dyella terrae strain JS14-6 (NR_044540) & 92.50 \\
\hline 20 & MT703044 & Dyella terrae strain JS14-6 (NR_044540) & 91.00 \\
\hline
\end{tabular}

\subsection{Growth Test}

Five bacterial strains $(1 C, 2 C, 3 C, 4 C$ and $5 C)$, isolated in a previous experiment from $S 1$ and S2 spring waters, and identified by sequencing of partial $16 \mathrm{~S}$ rDNA together with the new isolates, were subjected to growth tests with four different recalcitrant hydrocarbons, naphthalene, phenanthrene, pristane and hexadecane (Table 6). These isolates were identified as Achromobacter sp. (3C) and Pseudomonas sp. (1C, 2C, 4C and 5C).

Table 6. Growth test results after 4 weeks (bacterial growth: + slight; ++ moderate; +++ high).

\begin{tabular}{ccccc}
\hline Isolate & Naphthalene & Phenanthrene & Pristane & Hexadecane \\
\hline $1 C$ & + & + & + & ++ \\
$2 \mathrm{C}$ & + & +++ & +++ & ++ \\
$3 \mathrm{C}$ & + & ++ & ++ & ++ \\
$4 \mathrm{C}$ & + & +++ & ++ & ++ \\
$5 \mathrm{C}$ & + & + & + & ++ \\
\hline
\end{tabular}

As shown in Table 6, some of the Pseudomonas sp. isolates (2C and 4C) have returned the best results when supplementing phenanthrene and pristane as the only carbon sources. All the isolates gave equivalent results for the growth on medium containing naphthalene and hexadecane.

\subsection{Determination of the Emulsifying Capacity and Emulsion Index}

The 11 identified strains were tested for emulsion capacity. Moreover, one strain of Escherichia coli and one of Bacillus subtilis were used as controls (Table 7). 
Table 7. Emulsifying capacity results (EC\%) (- absence; + presence).

\begin{tabular}{ccc}
\hline Strain & EC & EC\% \\
\hline Proteobacteria bacterium strain 3 & - & 0 \\
Pseudomonas sp. strain 4 & + & 60 \\
Cupriavidus sp. strain 7 & - & 0 \\
Pseudomonas sp. strain 8 & + & 60 \\
Stenotrophomonas sp. strain 10 & - & 0 \\
Proteobacteria bacterium strain 15 & - & 0 \\
Proteobacteria bacterium strain 16 & + & 30 \\
Proteobacteria bacterium strain 18 & + & 60 \\
Proteobacteria bacterium strain 20 & + & 60 \\
Pseudomonas sp. strain 1C & + & 40 \\
Achromobacter sp. strain 3C & + & 50 \\
Escherichia coli (negative control) & - & 0 \\
Bacillus subtilis (positive control) & + & 50 \\
\hline
\end{tabular}

Seven out of the 11 bacterial strains produced emulsion with diesel fuel, most of which with an EC\% greater than $50 \%$. As shown in Figure 7, the stability of the emulsions (E\%) after 24 (t24) and $48 \mathrm{~h} \mathrm{(t48)} \mathrm{was} \mathrm{higher} \mathrm{for} \mathrm{Pseudomonas} \mathrm{sp.} \mathrm{strain} 8$ and Proteobacteria bacterium strain 18. After 24 and $48 \mathrm{~h}$, a decrease of $17 \%$ and $20 \%$, and $15 \%$ and $23 \%$, was observed for the strains 8 and 18, respectively. The emulsion of the Proteobacteria bacterium strain 16 was much less stable with a difference from $t_{0}$ to $\mathrm{t}_{24}$ of $70 \%$ and exhausted after $48 \mathrm{~h}$.

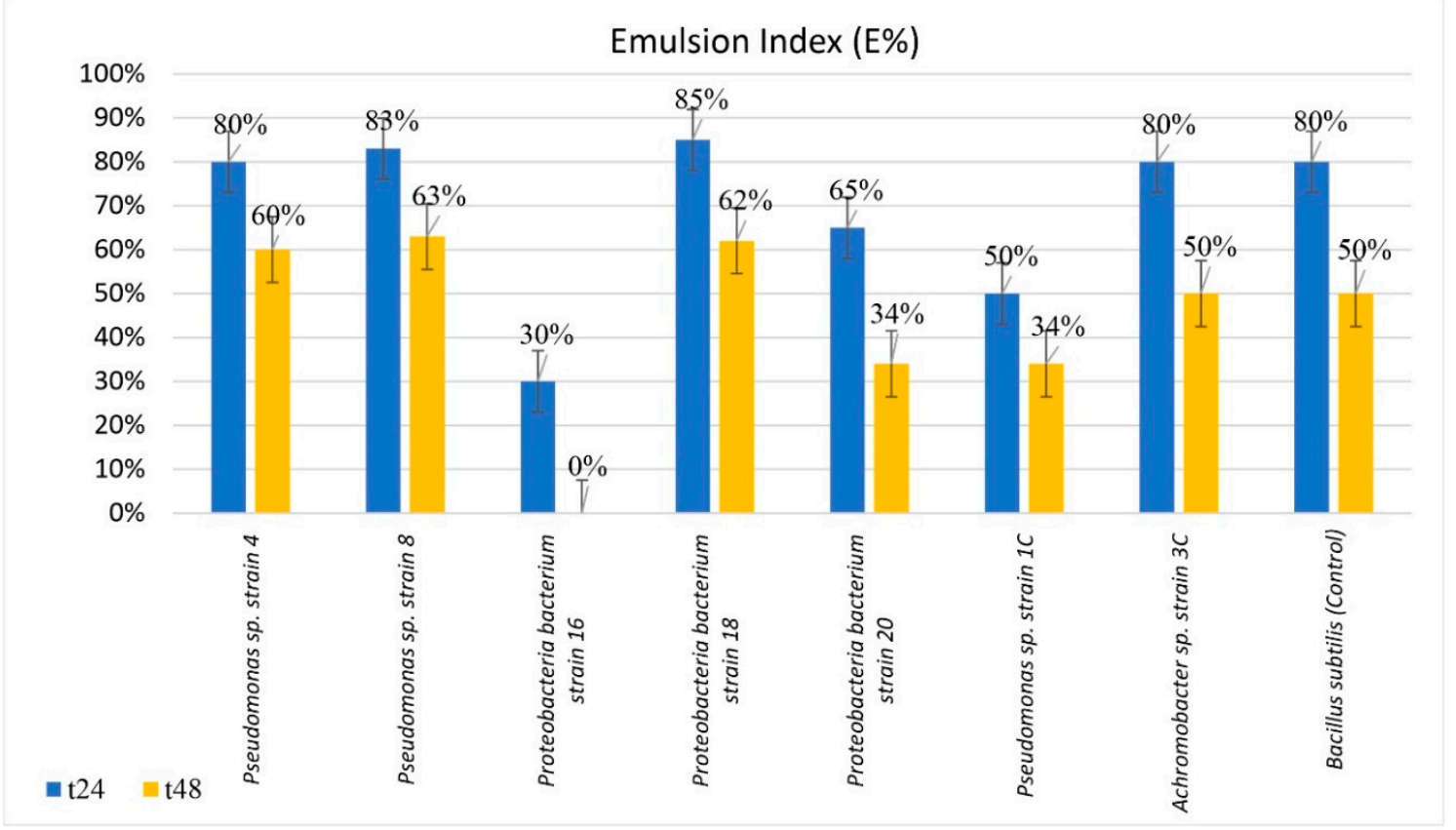

Figure 7. Histogram with emulsion index results (E\%) of the strains that showed emulsifying capacity, respectively, at time $t_{24}$ and $t_{48}$. The error used in the histogram is "the standard error".

\section{Discussion and Conclusions}

Petroleum hydrocarbon contamination is an issue of major concern worldwide. These compounds represent the most common environmental pollutants and their presence is destructive to the ecosystem and economic and human health [44]. The clean-up of hydrocarbon-contaminated sites is expensive and time consuming; however, bioremediation is a cost-effective and environmentally safe approach for petroleum hydrocarbon contamination (PHC) removal [44]. This technology involves the use of living organisms such as microbes and/or plants to reduce/degrade, eliminate and transform contaminants 
present in soils, sediments and water and has gained wider acceptance in recent years for all its potential [45]. In fact, although oil pollution is difficult to treat, indigenous bacteria can ultimately degrade or metabolize most petroleum hydrocarbons encountered in the environment because of their energetic and carbon needs for growth and reproduction, as well as the requirement to relieve physiological stress caused by their presence [46-48]. Accordingly, petroleum hydrocarbon-degrading bacteria, which have evolved as a result of existing in close proximity to naturally occurring petroleum hydrocarbons in the environment, represent suitable candidates for the treatment of oil polluted sites and to achieve the best purification effect [49-51].

An understanding of the temporal and spatial structures, functions, interactions, and population dynamics of microbial communities is critical for biotechnological development, environmental protection, and human health [52] so much that several methods have been employed to reveal microbial community composition, function and responses to environmental changes, in various environments and different contexts [53-60]. The main goal of this research was to analyze microbial communities in a site in southern Italy characterized by the presence of hydrocarbons of natural origin, by using a multidisciplinary approach based on microbiological, geological and hydrogeological investigations.

In detail, bacterial communities of two springs (S1 and S2), the surrounding soils, and groundwater ( $\mathrm{P}_{\text {art }}$ well) were studied through a combination of molecular and culture-dependent methodologies to explore the biodiversity at the study site, to isolate microorganisms with degradative abilities and to assess their potential to develop effective strategies to restore the environmental quality.

The two hydrocarbon springs S1 and S2 are linked to the recharge in a local aquifer system and distributed along a fault zone that favors the rise of fluids and hydrocarbons within the shallow low-permeability media. This hydrogeological behavior of the fault zone is not surprising when analyzing the possible roles (conduit, barrier, combined conduit-barrier systems) that these zones can play from the hydraulic point of view, depending on the relative percentage of fault core and damage zone [61-67]. In many aquifer systems worldwide, comparable with the studied one, both structural and hydrogeological approaches demonstrated the possible migration of fluids within fault zones acting as high- or low-flow discontinuities [68-74]. This evidence was further confirmed by the presence of $\mathrm{H}_{2} \mathrm{~S}$ at spring $\mathrm{S} 1$.

Chemical analyses of hydrocarbons highlighted the existence of several and different PAHs, such as Naphthalene, Benzo(b)fluoranthene, Benzo(k)fluoranthene, Benzo(g,h,i)perylene, Indene(1,2,3-c,d)pyrene, Chrysene, Anthracene, Phenanthrene, Fluoranthene, Benzo(j)fluoranthene, Dibenzo(a,h)anthracene, Pyrene and Dibenzo(a,l)pyrene in spring waters and soils. Generally, polycyclic aromatic hydrocarbons are chemicals with various structures and varied toxicity, stable, persistent in the environment, and resistant to degradation [75,76]. Chemically, they are comprised of two or more benzene rings bonded in linear, cluster, or angular arrangements [75]. The increase in the number of fused rings leads to higher hydrophobicity and recalcitrance to microbial degradation [77]. The continuous interaction with hydrocarbons could have influenced the bacterial communities of the two springs and the soils, naturally selecting some strains capable to biodegrade these pollutants.

The NGS results allowed us to obtain detailed information about the composition of microbial communities and revealed the dominance of species belonging to the phylum Proteobacteria. In this very large phylum of Gram-negative organisms, the majority of the formally described genera of hydrocarbon-degrading bacteria is included [78]; thus, it is likely that the continuous outflow of oil over time led to a stable and highly specialized microbiota, particularly adapted to grow and thrive in those environmental conditions. However, in addition to Proteobacteria, it was possible to also detect other autochthonous hydrocarbon-oxidizing bacteria affiliated to other phyla (e.g., species of the genera Flavobacterium and Gordonia), strengthening the assumption that natural exposure to pollutants can have impacted the structure and function of microbial populations. As expected, a higher biodiversity was found in soils compared to the aquatic ecosystems, generally lacking inputs of fresh, easily available organic carbon. In addition, beta-diversity analysis revealed a clear separation of soil, spring water, 
and groundwater samples and highlighted marked differences between S1 spring water microbial community and all the others. Although it is not surprising to find diverse microbial communities in different habitats due to their peculiar physico-chemical properties, it is likely that the observed results for the two springs reflect the influence of specific hydrogeological and other environmental factors that, on a local scale, shape bacterial community composition. As a matter of fact, $\mathrm{P}_{\text {art }}$-groundwater is fed by a deep confined aquifer. Differently, the springs S1 and S2 are fed by a common groundwater coming from the nearby carbonate aquifer, mixed with different fluids (rising along a fault zone) in different proportions. This is clearly demonstrated by differences in some physico-chemical features (Table 1) and hydrocarbon concentrations (Table 2), and are further supported when taking into consideration the different mean residence time of spring waters, determined through tritium analyses ( $\mathrm{S} 1=5.6$ to 6.9 tritium unit (TU), S2 $=6.8$ to $7.5 \mathrm{TU}$; the spring fed by the only carbonate aquifer $=8.4$ to 9.1 TU in Rizzo et al. [19]). These results are also in agreement with findings in other hydrogeological settings, where differences in microbial communities were clearly explained through the differences in (i) the aquifer type, (ii) the mixing between shallow groundwater and ascending fluids, (iii) the mixing between waters characterized by different salinity [53].

The traditional cultivation-based approach, performed by applying a selective pressure with diesel fuel supplementations, led to the isolation and identification of 11 aerobic hydrocarbon-oxidizing proteobacteria. Most of the bacteria isolated and identified belong, or are related, to genera or species known for their degradation abilities of polycyclic aromatic hydrocarbons [79-85]. The results are in line with those obtained by chemical analyses, which showed higher concentrations of these compounds at the investigated site. It is interesting to note that microorganisms of the genera Hydrogenophaga, Sulfuritalea and Sulfurovum, whose abundant presence was revealed by DNA-based analyses, have not been isolated after the enrichment procedures. This "paradox" can be explained by the theory of the "Great Plate Count Anomaly" [86], which refers to the observation that only a small fraction (0.01-1\%) of the microorganisms present in the environment can be cultivated in the laboratory. Despite this, the cultivation procedures led to the isolation of bacterial strains showing low values of $16 \mathrm{~S}$ rRNA gene sequence identity with known species, contributing to get insights into the hidden microbial diversity of the analyzed ecosystem.

Some of the isolates were found to be able to grow better when phenanthrene was supplied as the sole carbon source compared to other simpler aliphatic and aromatic hydrocarbons. Subsequently, their emulsifying capacity was assessed and the emulsion index was calculated. Seven out of the 11 isolated bacterial strains produced emulsion with diesel fuel (most of them showing EC values greater than $50 \%$ ) with high stability after $24 \mathrm{~h}$ and, in some cases, after $48 \mathrm{~h}$. The tests have clearly demonstrated the capability of some strains to increase hydrocarbon bioavailability, most likely through the production of biosurfactants. These compounds are naturally derived surfactants produced from biological entities (especially microorganisms), which can be utilized as a cost-effective and eco-friendly mean to enhance bioremediation of oil components, including PAHs, in the natural environment. Fungi, bacteria, and yeasts belonging to different species and strains are known for producing biosurfactants of a diverse variety of molecular structures. Amongst the bacteria domain, the genera of Pseudomonas, Bacillus, and Acinetobacter dominate the literature space as excellent producers of biosurfactants [87]. For example, Bacillus subtilis is known for its ability to enhance diesel solubility [88] and to improve its degradation by producing surfactin, a lipoprotein-type biosurfactant [89].

In the late 1960s, biosurfactants attracted attention as hydrocarbon-dissolving agents as potential replacements for synthetic surfactants (usually toxic, hardly degraded by microorganism, and causing damage to the environment) especially in the food, pharmaceutical, and oil industries [90]. Bioemulsifiers get accumulated at the interphase between the two immiscible phases by which they can reduce the surface tension, thereby increasing the solubility and emulsification of the immiscible phases. Accordingly, these compounds may convert insoluble substrate into soluble substrates, increasing their bioavailability and making them usable by the microorganisms [91]. 
In conclusion, the data collected in this study pave the way for further investigations finalized at exploiting both (i) the degradation ability of the bacterial isolates and/or microbial consortia to remediate hydrocarbon-contaminated sites through strategies like biostimulation or bioaugmentation, and (ii) the capability to produce molecules with a good promoting effect for the restoration of oil polluted matrices. In addition, the isolation of strains showing a $16 \mathrm{~S}$ rRNA gene sequence identity $<97 \%$ with those available in the genetic sequence database, constitutes a significant result and represents a further exciting challenge to fully unravel the existing biodiversity at the study site and expand the current knowledge on biodegradation processes, also through the description and characterization of novel bacterial species.

Supplementary Materials: The following are available online at http://www.mdpi.com/2073-4441/12/8/2090/s1, Figure S1: Geological section W-E crossing the Agri Valley, Figure S2: Hydrocarbon springs S1 and S2, Figure S3: Rarefaction curves of spring water, groundwater, and soil samples collected at the study site.

Author Contributions: Conceptualization, A.B., A.M.S., and F.C.; formal analysis, P.R.; investigation, P.R., M.M., S.R.; supervision, A.B., A.M.S., and F.C.; validation, P.R.; visualization, P.R.; writing—original draft, P.R., and A.B.; writing-review \& editing, P.R., A.B., A.M.S., and F.C. All authors have read and agreed to the published version of the manuscript.

Funding: This research received no external funding.

Acknowledgments: We warmly acknowledge Dario Avagliano, Francesco Coraggio, Antonella Caputi, and Fabrizio Micucci (ENIS.p.A., Distretto Meridionale) for providing some of the data used in the present work and for useful discussions. This work has benefited from the equipment and framework of the COMP-HUB Initiative, funded by the 'Departments of Excellence' program of the Italian Ministry for Education, University and Research (MIUR, 2018-2022). We are grateful to the reviewers for their constructive comments and valuable suggestions.

Conflicts of Interest: There are no conflicts of interest related to this paper.

\section{References}

1. Espinoza-Tofalos, A.; Daghio, M.; Palma, E.; Aulenta, F.; Franzetti, A. Structure and functions of hydrocarbon-degrading microbial communities in bioelectrochemical systems. Water 2020, 12, 343. [CrossRef]

2. Varjani, S.J.; Upasani, V.N. Biodegradation of petroleum hydrocarbons by oleophilic strain of Pseudomonas aeruginosa NCIM 5514. Bioresour. Technol. 2016, 222, 195-201. [CrossRef] [PubMed]

3. Costa, A.S.; Romão, L.P.C.; Araújo, B.R.; Lucas, S.C.O.; Maciel, S.T.A.; Wisniewski, A., Jr.; Alexandre, M.D.R. Environmental strategies to remove volatile aromatic fractions (BTEX) from petroleum industry wastewater using biomass. Bioresour. Technol. 2012, 105, 31-39. [CrossRef] [PubMed]

4. Zhang, Z.; Hou, Z.; Yang, C.; Ma, C.; Tao, F.; Xu, P. Degradation of n-alkanes and polycyclic aromatic hydrocarbons in petroleum by a newly isolated Pseudomonas aeruginosa DQ8. Bioresour. Technol. 2011, 102, 4111-4116. [CrossRef] [PubMed]

5. Chandra, S.; Sharma, R.; Singh, K.; Sharma, A. Application of bioremediation technology in the environment contaminated with petroleum hydrocarbon. Ann. Microbiol. 2013, 63, 417-431. [CrossRef]

6. Souza, E.C.; Vessoni-Penna, T.C.; de Souza Oliveira, R.P. Biosurfactant-enhanced hydrocarbon bioremediation: An overview. Int. Biodeter. Biodegr. 2014, 89, 88-94. [CrossRef]

7. Meckenstock, R.U.; Boll, M.; Mouttaki, H.; Koelschbach, J.S.; Tarouco, P.C.; Weyrauch, P.; Himmelberg, A.M. Anaerobic degradation of benzene and polycyclic aromatic hydrocarbons. J. Mol. Microbiol. Biotechnol. 2016, 26, 92-118. [CrossRef]

8. Chaudhary, D.K.; Kim, J. New insights into bioremediation strategies for oil-contaminated soil in cold environments. Int. Biodeter. Biodegr. 2019, 142, 58-72. [CrossRef]

9. Alberti, L.; Lombi, S.; Zanini, A. Identifying sources of chlorinated aliphatic hydrocarbons in a residential area in Italy using the integral pumping test method. Hydrogeol. J. 2011, 19, 1253-1267. [CrossRef]

10. Varjani, S.J. Microbial degradation of petroleum hydrocarbons. Bioresour. Technol. 2017, 223, 277-286. [CrossRef]

11. Daghio, M.; Aulenta, F.; Vaiopoulou, E.; Franzetti, A.; Arends, J.B.A.; Sherry, A.; Suárez-Suárez, A.; Head, I.M.; Bestetti, G.; Rabaey, K. Electrobioremediation of oil spills. Water Res. 2017, 114, 351-370. [CrossRef] [PubMed]

12. Abbasian, F.; Lockington, R.; Mallavarapu, M.; Naidu, R. A comprehensive review of aliphatic hydrocarbon biodegradation by bacteria. Appl. Biochem. Biotechnol. 2015, 176, 670-699. [CrossRef] [PubMed] 
13. Bosco, F.; Casale, A.; Chiampo, F.; Godio, A. Removal of diesel oil in soil microcosms and implication for geophysical monitoring. Water 2019, 11, 1661. [CrossRef]

14. Balaban, N.; Yankelzon, I.; Adar, E.; Gelman, F.; Ronen, Z.; Bernstein, A. The spatial distribution of the microbial community in a contaminated aquitard below an industrial zone. Water 2019, 11, 2128. [CrossRef]

15. Varjani, S.J.; Thaker, M.B.; Upasani, V.N. Optimisation of growth conditions of native hydrocarbon utilizing bacterial consortium "HUBC" obtained from petroleum pollutant contaminated sites. Indian J. Appl. Res. 2014, 4, 474-476.

16. Cazzini, F.F. The history of the upstream oil and gas industry in Italy. In History of the European Oil and Gas Industry; Craig, J., Gerali, F., MacAulay, F., Sorkhabi, R., Eds.; Geological Society Special Publications: London, UK, 2018; Volume 465, pp. 243-274.

17. Scandone, P.; Sgrosso, I. Flysch con Inocerami nella valle del Cavolo presso Tramutola (Lucania). Boll. Soc. Nat. Napoli 1964, 73, 166-175.

18. Olita, F. Investigation of the Natural Hydrocarbon Manifestations and 3D Reconstruction of the Reservoir in the Tramutola Area (Basilicata). Master's Thesis, University of Basilicata, Potenza, Italy, 2019.

19. Rizzo, P.; Bucci, A.; Sanangelantoni, A.M.; Iacumin, P.; Celico, F. Coupled microbiological-isotopic approach for studying hydrodynamics in deep reservoirs: The case of the Val d'Agri oilfiled (southern Italy). Water 2020, 12, 1483. [CrossRef]

20. De Vita, P.; Allocca, V.; Celico, F.; Fabbrocino, S.; Cesaria, M.; Monacelli, G.; Musilli, I.; Piscopo, V.; Scalise, A.R.; Summa, G.; et al. Hydrogeology of continental Southern Italy. J. Maps 2018, 14, 230-241.

21. Berserzio, R.; Felletti, F.; Giudici, M.; Miceli, A.; Zembo, I. Aquifer analogues to assist modeling of groundwater flow: The Pleistocene aquifer complex of the Agri Valley (Basilicata). Mem. Descr. Carta Geol. d'It. 2007, LXXVI, 51-66.

22. Azienda Generale Italiana Petroli, Ricerche petrolifere (AGIP) (Roma, Italy). Cantiere di Tramutola, Sondaggio N. 2. in Italian, 1939; Unpublished.

23. Patacca, E.; Scandone, P.; Bellatalla, M.; Perilli, N.; Santini, U. The Numidian-sand event in the Southern Apennines. Mem. Sci. Geol. Padova 1992, 43, 297-337.

24. Menardi Noguera, A.; Rea, G. Deep structure of the Campanian-Lucanian arc (southern Apennine, Italy). Tectonophysics 2000, 324, 239-265. [CrossRef]

25. U.S. EPA. Method 3510C (SW-846): Separatory Funnel Liquid-Liquid Extraction; U.S. Environmental Protection Agency: Washington, DC, USA, 1996.

26. U.S. EPA. Method 5030C (SW-846): Purge-and-Trap for Aqueous Samples Revision 3; U.S. Environmental Protection Agency: Washington, DC, USA, 2003.

27. U.S. EPA. Method 8015D (SW-846): Nonhalogenated Organics Using GC/FID Revision 4; U.S. Environmental Protection Agency: Washington, DC, USA, 2003.

28. U.S. EPA. Method 3550C (SW-846): Ultrasonic Extraction; U.S. Environmental Protection Agency: Washington, DC, USA, 2007.

29. U.S. EPA. Method 5021A (SW-846): Volatile Organic Compounds (VOCs) in Various Sample Matrices Using Equilibrium Headspace Analysis; U.S. Environmental Protection Agency: Washington, DC, USA, 2014.

30. U.S. EPA. Method 8270E (SW-846) Semivolatile Organic Compounds by Gas Chromatography/Mass Spectrometry (GC/MS); U.S. Environmental Protection Agency: Washington, DC, USA, 2018.

31. Milani, C.; Hevia, A.; Foroni, E.; Duranti, S.; Turroni, F.; Lugli, G.A.; Margolles, A. Assessing the fecal microbiota: An optimized ion torrent 16S rRNA gene-based analysis protocol. PLoS ONE 2013, 8, e68739. [CrossRef] [PubMed]

32. Caporaso, J.G.; Kuczynski, J.; Stombaugh, J.; Bittinger, K.; Bushman, F.D.; Costello, E.K.; Huttley, G.A. QIIME allows analysis of high-throughput community sequencing data. Nat. Methods 2010, 7, 335. [CrossRef] [PubMed]

33. Callahan, B.J.; McMurdie, P.J.; Rosen, M.J.; Han, A.W.; Johnson, A.J.; Holmes, S.P. DADA2: High-resolution sample inference from Illumina amplicon data. Nat. Methods 2016, 13, 581-583. [CrossRef] [PubMed]

34. Bokulich, N.A.; Kaehler, B.D.; Rideout, J.R.; Dillon, M.; Bolyen, E.; Knight, R.; Caporaso, J.G. Optimizing taxonomic classification of marker-gene amplicon sequences with QIIME 2's q2-feature-classifier plugin. Microbiome 2018, 6, 90. [CrossRef] 
35. Quast, C.; Pruesse, E.; Yilmaz, P.; Gerken, J.; Schweer, T.; Yarza, P.; Glöckner, F.O. The SILVA ribosomal RNA gene database project: Improved data processing and web-based tools. Nucleic Acids Res. 2012, 41, D590-D596. [CrossRef]

36. Bushnell, L.D.; Haas, H.F. The utilization of certain hydrocarbons by microorganisms. J. Bacteriol. 1941, 41, 653-673. [CrossRef]

37. Mohebali, G.; Ball, A.; Kaytash, A.; Rasekh, B. Stabilization of water/gas oil emulsions by desulfurizing cells of Gordonia alkanivorans RIPI90A. Microbiology 2007, 153, 1573-1581. [CrossRef]

38. Magic-Knezev, A.; Wullings, B.; Van der Kooij, D. Polaromonas and Hydrogenophaga species are the predominant bacteria cultured from granular activated carbon filters in water treatment. J. Appl. Microbiol. 2009, 107, 1457-1467. [CrossRef]

39. Aburto, A.; Peimbert, M. Degradation of a benzene-toluene mixture by hydrocarbon-adapted bacterial communities. Ann. Microbiol. 2011, 61, 553-562. [CrossRef]

40. Rahman, K.S.M.; Thahira-Rahman, J.; Lakshmanaperumalsamy, P.; Banat, I.M. Towards efficient crude oil degradation by a mixed bacterial consortium. Bioresour. Technol. 2002, 85, 257-261. [CrossRef]

41. Hemalatha, S.; Veeramanikandan, P. Characterization of aromatic hydrocarbon degrading bacteria from petroleum contaminated sites. J. Environ. Prot. 2011, 2, 243-254. [CrossRef]

42. Franzetti, A.; Caredda, P.; Ruggeri, C.; La Colla, P.; Tamburini, E.; Papacchini, M.; Bestetti, G. Potential applications of surface active compounds by Gordonia sp. strain BS29 in soil remediation technologies. Chemosphere 2009, 75, 801-807. [CrossRef] [PubMed]

43. Sperfeld, M.; Diekert, G.; Studenik, S. Anaerobic aromatic compound degradation in Sulfuritalea hydrogenivorans sk43H. FEMS Microbiol. Ecol. 2018, 95, fiy199. [CrossRef] [PubMed]

44. Truskewycz, A.; Gundry, T.D.; Khudur, L.S.; Kolobaric, A.; Taha, M.; Aburto-Medina, A.; Ball, A.S.; Shahsavari, E. Petroleum hydrocarbon contamination in terrestrial ecosystems-fate and microbial responses. Molecules 2019, 24, 3400. [CrossRef]

45. Dhir, B. Bioremediation technologies for the removal of pollutants. In Advances in Environmental Biotechnology; Kumar, R., Sharma, A., Ahluwalia, S., Eds.; Springer: Singapore, 2017.

46. Hazen, T.C.; Dubinsky, E.A.; DeSantis, T.Z.; Andersen, G.L.; Piceno, Y.M.; Singh, N.; Stringfellow, W.T. Deep-sea oil plume enriches indigenous oil-degrading bacteria. Science 2010, 330, 204-208. [CrossRef]

47. Kleindienst, S.; Paul, J.H.; Joye, S.B. Using dispersants after oil spills: Impacts on the composition and activity of microbial communities. Nat. Rev. Microbiol. 2015, 13, 388-396. [CrossRef]

48. Xu, X.; Liu, W.; Tian, S.; Wang, W.; Qi, Q.; Jiang, P.; Gao, X.; Li, F.; Li, H.; Yu, H. Petroleum hydrocarbon-degrading bacteria for the remediation of oil pollution under aerobic conditions: A perspective analysis. Front. Microbiol. 2018, 9, 2885. [CrossRef]

49. Margesin, R.; Labbé, D.; Schinner, F.; Greer, C.W.; Whyte, L.G. Characterization of hydrocarbon-degrading microbial populations in contaminated and pristine alpine soils. Appl. Environ. Microbiol. 2003, 69, 3085-3092. [CrossRef]

50. Ron, E.Z.; Rosenberg, E. Enhanced bioremediation of oil spills in the sea. Curr. Opin. Biotechnol. 2014, 27, 191-194. [CrossRef]

51. Lea-Smith, D.J.; Biller, S.J.; Davey, M.P.; Cotton, C.A.; Sepulveda, B.M.P.; Turchyn, A.V.; Howe, C.J. Contribution of cyanobacterial alkane production to the ocean hydrocarbon cycle. Proc. Natl. Acad. Sci. USA 2015, 112, 13591-13596. [CrossRef] [PubMed]

52. Bucci, A.; Petrella, E.; Celico, F.; Naclerio, G. Use of molecular approaches in hydrogeological studies: The case of carbonate aquifers in southern Italy. Hydrogeol. J. 2017, 25, 1017-1031. [CrossRef]

53. Bucci, A.; Naclerio, G.; Allocca, V.; Celico, P.; Celico, F. Potential use of microbial community investigations to analyse hydrothermal systems behaviour: The case of Ischia Island, Southern Italy. Hydrol. Process. 2011, 25, 1866-1873. [CrossRef]

54. Bucci, A.; Petrella, E.; Naclerio, G.; Gambatese, S.; Celico, F. Bacterial migration through low-permeability fault zones in compartmentalised aquifer systems: A case study in Southern Italy. Int. J. Speleol. 2014, 43, 273-281. [CrossRef]

55. Bucci, A.; Allocca, V.; Naclerio, G.; Capobianco, G.; Divino, F.; Fiorillo, F.; Celico, F. Winter survival of microbial contaminants in soil: An in situ verification. J. Environ. Sci. 2015, 27, 131-138. [CrossRef] [PubMed] 
56. Bucci, A.; Petrella, E.; Naclerio, G.; Allocca, V.; Celico, F. Microorganisms as contaminants and natural tracers: A 10-year research in some carbonate aquifers (southern Italy). Environ. Earth Sci. 2015, 74, 173-184. [CrossRef]

57. Crescenzo, R.; Mazzoli, A.; Cancelliere, R.; Bucci, A.; Naclerio, G.; Baccigalupi, L.; Cutting, S.M.; Ricca, E.; Iossa, S. Beneficial effects of carotenoid-producing cells of Bacillus indicus HU16 in a rat model of diet-induced metabolic syndrome. Benef. Microbes 2017, 8, 823-831. [CrossRef]

58. Di Luccia, B.; Mazzoli, A.; Cancelliere, R.; Crescenzo, R.; Ferrandino, I.; Monaco, A.; Bucci, A.; Naclerio, G.; Iossa, S.; Ricca, E.; et al. Lactobacillus gasseri SF1183 protects the intestinal epithelium and prevents colitis symptoms in vivo. J. Func. Foods 2018, 42, 195-202. [CrossRef]

59. Petrella, E.; Bucci, A.; Ogata, K.; Zanini, A.; Naclerio, G.; Chelli, A.; Francese, R.; Boschetti, T.; Pittalis, D.; Celico, F. Hydrodynamics in evaporate-bearing fine-grained successions investigated through an interdisciplinary approach: A test study in Southern Italy. Geofluids 2018, 2018, 5978597. [CrossRef]

60. Pietrangelo, L.; Bucci, A.; Maiuro, L.; Bulgarelli, D.; Naclerio, G. Unraveling the composition of the root-associated bacterial microbiota of Phragmites australis and Typha latifolia. Front. Microbiol. 2018, 9, 1650. [CrossRef]

61. Celico, P. Prospezioni Idrogeologiche; Liguori Editore: Napoli, Italy, 1986.

62. Antonellini, M.; Aydin, A. Effect of faulting on fluid flow in por-ous sandstones: Petrophysical proper-ties. Am. Assoc. Petrol. Geol. Bull. 1994, 78, 355-377.

63. Newman, J.; Mitra, G. Fluid-influenced deformation and recrystalli-zation of dolomite at low temperatures along a natural fault zone, Mountain City window, Tennessee. Geol. Soc. Am. Bull. 1994, 106, 1267-1280. [CrossRef]

64. Goddard, J.V.; Evans, J.P. Chemical changes and fluid-rock inter-action in faults of crystalline thrust sheets, northwestern Wyoming, USA. J. Struct. Geol. 1995, 17, 533-547. [CrossRef]

65. Caine, J.S.; Evans, J.P.; Forster, C.B. Fault zone architecture and per-meability structure. Geology 1996, 24, 1025-1028. [CrossRef]

66. Bense, V.F.; Van den Berg, E.H.; Van Balen, R.T. Deformation mecha-nisms and hydraulic properties of fault zones in unconsolidated sediments; the Roer Valley Rift System, The Nether-lands. Hydrogeol. J. 2003, 11, 319-332. [CrossRef]

67. Fairley, J.P.; Hinds, J.J. Field observation of fluid circulation patterns in a normal fault system. Geophys. Res. Lett. 2004, 31, 1-4. [CrossRef]

68. Celico, F.; Petrella, E.; Celico, P. Hydrogeological behaviour of some fault zones in a carbonate aquifer of Southern Italy: An experimentally based model. Terra Nova 2006, 18, 308-313. [CrossRef]

69. Agosta, F.; Alessandroni, M.; Antonellini, M.; Tondi, E.; Giorgioni, M. From fractures to flow: A field-based quantitative analysis of an outcropping carbonate reservoir. Tectonophysics 2010, 490, 197-213. [CrossRef]

70. Aquino, D.; Petrella, E.; Florio, T.; Celico, P.; Celico, F. Complex hydraulic interactions between compartmentalized carbonate aquifers and heterogeneous siliciclastic successions: A case study in southern Italy. Hydrol. Process. 2015, 29, 4252-4263. [CrossRef]

71. Petrella, E.; Aquino, D.; Fiorillo, F.; Celico, F. The effect of low-permeability fault zones on groundwater flow in a compartmentalized system. Experimental evidence from a carbonate aquifer (Southern Italy). Hydrol. Process. 2015, 29, 1577-1587. [CrossRef]

72. Giuffrida, A.; La Bruna, V.; Castelluccio, P.; Panza, E.; Rustichelli, A.; Tondi, E.; Giorgini, M.; Agosta, F. Fracture simulation parameters of fractured reservoirs: Analogy with outcropping carbonates of the Inner Apulian Platform, southern Italy. J. Struct. Geol. 2019, 123, 18-41. [CrossRef]

73. Hernandez-Diaz, R.; Petrella, E.; Bucci, A.; Naclerio, G.; Feo, A.; Sferra, G.; Chelli, A.; Zanini, A.; Gonzales-Hernandez, P.; Celico, F. Integrating hydrogeological and microbiological data and modelling to characterize the hydraulic features and behavior of coastal carbonate aquifers: A case in Western Cuba. Water 2019, 11, 1989. [CrossRef]

74. Ferraro, F.; Agosta, F.; Prasad, M.; Vinciguerra, S.; Violay, M.; Giorgioni, M. Pore space properties in carbonate fauklt rocks of peninsular Italy. J. Struct. Geol. 2020, 130, 103913. [CrossRef]

75. Abdel-Shafy, H.I.; Mansour, M.S.M. A review on polycyclic aromatic hydrocarbons: Source, environmental impact, effect on human health and remediation. Egypt. J. Pet. 2016, 25, 107-123. [CrossRef] 
76. Martirani-Von Abercron, S.-M.; Pacheco, D.; Benito-Santano, P.; Marín, P.; Marqués, S. Polycyclic aromatic hydrocarbon-induced changes in bacterial community structure under anoxic nitrate reducing conditions. Front. Microbiol. 2016, 7, 1775. [CrossRef]

77. Wang, W.; Wang, L.; Shao, Z. Polycyclic aromatic hydrocarbon (PAH) degradation pathways of the obligate marine PAH degrader Cycloclasticus sp. Strain P1. Appl. Environ. Microbiol. 2018, 84, e01261-18. [CrossRef]

78. Prince, R.C.; Gramain, A.; McGenity, T.J. Prokaryotic Hydrocarbon Degraders. In Handbook of Hydrocarbon and Lipid Microbiology; Timmis, K.N., Ed.; Springer: Berlin/Heidelberg, Germany, 2010.

79. Jahin, H.S.; Gaber, S.E.; Ewida, A.Y.I. Biodegradation of phenanthrene by native bacterial strains isolated from River Nile water in Egypt. Nat. Sci. J. 2014, 12, 1-8.

80. Farjadfard, S.; Borghei, S.M.; Hassani, A.H.; Yakhchali, B.; Ardjmand, M.; Zeinali, M. Efficient biodegradation of naphthalene by a newly characterized indigenous Achromobacter sp. FBHYA2 isolated from Tehran Oil Refinery Complex. Water Sci. Technol. 2012, 66, 594-602. [CrossRef]

81. Gracioso, L.H.; Vieira, P.B.; Baltazar, M.P.; Avanzi, I.R.; Karolski, B.; Nascimento, C.A.; Perpetuo, E.A. Removal of phenolic compounds from raw industrial wastewater by Achromobacter sp. isolated from a hydrocarbon-contaminated area. Water Environ. J. 2019, 33, 40-50. [CrossRef]

82. Espinoza Tofalos, A.; Daghio, M.; González, M.; Papacchini, M.; Franzetti, A.; Seeger, M. Toluene degradation by Cupriavidus metallidurans $\mathrm{CH} 34$ in nitrate-reducing conditions and in Bioelectrochemical Systems. FEMS Microbiol. Lett. 2018, 365, fny119.

83. Qu, Y.; Shen, E.; Ma, Q.; Zhang, Z.; Liu, Z.; Shen, W.; Zhou, J. Biodegradation of indole by a newly isolated Cupriavidus sp. SHE. J. Environ. Sci. 2015, 34, 126-132. [CrossRef] [PubMed]

84. Juhasz, A.L.; Stanley, G.A.; Britz, M.L. Microbial degradation and detoxification of high molecular weight polycyclic aromatic hydrocarbons by Stenotrophomonas maltophilia strain VUN 10,003. Lett. Appl. Microbiol. 2000, 30, 396-401. [CrossRef] [PubMed]

85. Gao, S.; Seo, J.S.; Wang, J.; Keum, Y.S.; Li, J.; Li, Q.X. Multiple degradation pathways of phenanthrene by Stenotrophomonas maltophilia C6. Int. Biodeter. Biodegr. 2013, 79, 98-104. [CrossRef] [PubMed]

86. Harwani, D. The great plate count anomaly and the unculturable bacteria. Microbiology 2013, 2, 350-351. [CrossRef]

87. Fenibo, E.O.; Ijoma, G.N.; Selvarajan, R.; Chikere, C.B. Microbial surfactants: The next generation multifunctional biomolecules for applications in the petroleum industry and its associated environmental remediation. Microorganisms 2019, 7, 581. [CrossRef] [PubMed]

88. Mnif, I.; Ellouze-Chaabouni, S.; Ghribi, D. Economic production of Bacillus subtilis SPB1 biosurfactant using local agro-industrial wastes and its application in enhancing solubility of diesel. J. Chem. Technol. Biotechnol. 2013, 88, 779-787. [CrossRef]

89. Whang, L.M.; Liu, P.W.G.; Ma, C.C.; Cheng, S.S. Application of biosurfactants, rhamnolipid, and surfactin, for enhanced biodegradation of diesel-contaminated water and soil. J. Hazard. Mater. 2008, 151, 155-163. [CrossRef]

90. Sáenz-Marta, C.I.; Ballinas-Casarrubias M de Lourdes Rivera-Chavira, B.E.; Nevárez-Moorillón, G.V. Biosurfactants as Useful Tools in Bioremediation. In Advances in Bioremediation of Wastewater and Polluted Soil; Naofumi, S., Ed.; IntechOpen: London, UK, 2015; Volume 5.

91. Peele, K.A.; Ch, V.R.; Kodali, V.P. Emulsifying activity of a biosurfactant produced by a marine bacterium. 3 Biotech 2016, 6, 177. [CrossRef]

(C) 2020 by the authors. Licensee MDPI, Basel, Switzerland. This article is an open access article distributed under the terms and conditions of the Creative Commons Attribution (CC BY) license (http://creativecommons.org/licenses/by/4.0/). 